\title{
Assessment of selected quality fields of nursing care in neurosurgical wards
}

Rita Cassia Vieira'

Manoel Jacobsen Teixeira ${ }^{2}$ Wellingson Silva Paiva ${ }^{2}$

'School of Nursing, ${ }^{2}$ Division of Neurological Surgery, University of Sao Paulo Medical School, Sao Paulo, Brazil
This article was published in the following Dove Press journal:

Patient Preference and Adherence

5 February 2015

Number of times this article has been viewed

\section{Dear editor}

We read with great interest the recent study by Ślusarz et $\mathrm{al}^{1}$ published in the Patient Preference and Adherence journal. The nurse has a key role in caring for the human being in a comprehensive and holistic manner, providing a systematic assistance in promotion, prevention, protection, and rehabilitation of patients. ${ }^{2}$ Patient satisfaction about the care provided by the nursing staff is an important aspect to evaluate the quality of care and contributes in the improvement of treatment processes. ${ }^{3,4}$ In the study by Ślusarz et $\mathrm{al}^{1}$ the importance of evaluation of nursing care and its influence on the quality of care were emphasized.

A strong point of the paper is the instrument used to evaluate the patient expectations with respect to the service provided by the staff in several areas, which helps in identifying the areas of strengths and weaknesses of the quality of care. However, despite the questionnaire covers five areas, it is unspecific to assess the quality of nursing care. We believe that future studies are necessary to evaluate the quality of nursing care especially in the special population with neurosurgical diseases, and to identify the factors that influence the quality of assistance. ${ }^{3-5}$ An important consideration that should be mentioned in this study about evaluation of nursing care is hospital work context. In some health institutions, the nursing team may need to work in both professional administrative services and nursing care ${ }^{6}$ Hence, it is important for the authors to report whether the nursing teams perform exclusive roles in patients assistance alone or in administrative functions also.

Other important points of concern are that the authors do not mention details about sample size calculation and distribution of the sample in different institutions, which could ensure higher degrees of internal and external validity. The authors have presented results from a multicenter medical service-quality project executed by four university medical centers. Hence, information about distribution of the sample could enable comparison of the responses of patients regarding the evaluation of nursing care between different institutions, including number of patients and systematization of care provided by the nursing teams. These are some questions; however, these do not exclude the relevance of the results of this interesting paper.

\section{Disclosure}

The authors report no conflicts of interest in this work.

\section{References}

1. Ślusarz R, Biercewicz M, Barczykowska E, Haor B, Głowacka M. Assessment of selected quality fields of nursing care in neurosurgical wards: a prospective study of 530 people - multicenter studies. Patient Prefer Adherence. 2014;8:1113-1121. 
2. Savage EB. An Examination of the Changes in the Professional role of the Nurse Outside Ireland: A Report Prepared for the Commission on Nursing. Dublin: The Stationery Office; 1998.

3. Freitas JS, Silva AE, Minamisava R, Bezerra AL, Sousa MR. Quality of nursing care and satisfaction of patients attended at a teaching hospital. Rev Latino-Am Enfermagem. 2014;22(3):454-460.

4. Lyu H, Wick EC, Housman M, Freischlag JA, Makary MA. Patient satisfaction as a possible indicator of quality surgical care. JAMA Surg. 2013;148(4):362-367.
5. Papastavrou E, Andreou P, Tsangari H, Merkouris A. Linking patient satisfaction with nursing care: the case of care rationing - a correlational study. BMC Nurs. 2014;13:26.

6. Kieft RA, Brouwer BB, Francke AL, Delnoij DM. How nurses and their work environment affect patient experiences of the quality of care: a qualitative study. BMC Health Serv Res. 2014;14:249. 


\section{Authors' reply \\ Robert Ślusarz' \\ Monika Biercewicz ${ }^{2}$ \\ Ewa Barczykowska ${ }^{3}$ \\ Beata Haor ${ }^{4}$ \\ Mariola Głowacka ${ }^{5}$}

'Neurological and Neurosurgical Nursing Department, Collegium Medicum, Nicolaus Copernicus University, Bydgoszcz, ${ }^{2} \mathrm{Clinic}$ of Geriatrics, ${ }^{3}$ Nursing Department, Collegium Medicum, Nicolaus Copernicus University, Torun, ${ }^{4}$ Faculty of Health Science, University of Humanities and Economics in Wloclawek, Wloclawek, ${ }^{5}$ Institute of Health Sciences, State School of Higher Professional Education in Plock, Plock, Poland

Correspondence: Robert Ślusarz

Neurological and Neurosurgical Nursing Department CM, NCU, ul

Techników 3, 85-094 Bydgoszcz, Poland

Email zpielnin@cm.umk.pl

\section{Dear editor}

On behalf of all the authors for our publication, I would like to thank Rita Cassia Vieira, Manoel Jacobsen Teixeira, and Wellingson Silva Paiva for the interest in problematic aspects of the quality of nursing care. ${ }^{1}$ I believe that the commentary was made by doctors and I am glad that our work has interested those in the area of nursing care.

The commentary and questions from the authors of the letter are wholly appropriate in the issue addressing the need to specify the research tool - especially to specify the neurosurgical wards and assess the comparability of the results with other entities that ensure health care of patients after neurosurgical operations in a distant period, ie, Welfare and Nursing Homes or Long Term Care Homes.

Unfortunately, the aim of the research was only to assess the selected areas of nursing quality, with the focus on the satisfaction/evaluation of performed tasks in particular wards. That is the reason why only the sample of Anonymous Questionnaire - Patient's Satisfaction (QPS) was presented in the study.

The tool (QPS) serves to assess care in health care units (wards) and that was the aim of the authors - the assessment of one aspect - referring to nursing care. There is no way to compare those results with other entities providing health care of neurosurgical patients such as those in Welfare and Nursing Homes or Long Term Care Homes due to a different specificity of the functioning of these entities.

Of course, we also have the results from the other areas at our disposal. They include the assessment of doctors neurosurgeons by patients. However, the presentation of these results would go beyond the scope of the study.

\section{Disclosure}

The authors report no conflicts of interest in this communication.

\section{Reference}

1. Ślusarz R, Biercewicz M, Barczykowska E, Haor B, Głowacka M. Assessment of selected quality fields of nursing care in neurosurgical wards: a prospective study of 530 people - multicenter studies. Patient Prefer Adherence. 2014;8:1113-1121.

\section{Publish your work in this journal}

Patient Preference and Adherence is an international, peer-reviewed, open access journal that focuses on the growing importance of patient preference and adherence throughout the therapeutic continuum. Patient satisfaction, acceptability, quality of life, compliance, persistence and their role in developing new therapeutic modalities and compounds to optimize clinical outcomes for existing disease states are major areas of interest for the journal. This journal has been accepted for indexing on PubMed Central. The manuscript management system is completely online and includes a very quick and fair peer-review system, which is all easy to use. Visit http://www. dovepress.com/testimonials.php to read real quotes from published authors. 